\title{
Exporters, Engineers, and Blue-collar Workers
}

\author{
Irene Brambilla, Daniel Lederman, and Guido Porto
}

\begin{abstract}
This article investigates differences in the composition of employment between exporting and nonexporting firms. In particular, it asks whether exporting firms hire more engineers relative to blue-collar workers than nonexporting firms. In a stylized partialequilibrium model, firms produce goods of varying quality and exporters tend to produce higher quality goods, which are intensive in engineers relative to blue-collar workers. Firms are heterogeneous and more productive firms become exporters and have a higher demand for engineers. The article provides causal evidence in support of these theories using the Chilean Encuesta Nacional Industrial Anual (ENIA), an annual census of manufacturing firms. The results from an instrumental variable estimator suggest that Chilean exporters indeed utilize a higher share of engineers over blue-collar workers. JEL Codes: F13, F14
\end{abstract}

There is widespread evidence of both a wage and an employment premium in exporting vis-à-vis nonexporting firms (Bernard and Jensen 1999; Bernard et al. 2007). This article investigates differences the composition of employment of exporting firms. In particular, it asks whether exporting firms hire more engineers relative to blue-collar workers than nonexporting firms. This can happen because firms produce goods of varying quality and exporters tend to produce higher quality goods. As in the literature, more productive firms become exporters (Melitz 2003). In our framework, goods are produced with tasks using assignment rules (Acemoglu and Zilibotti 2001; Costinot and Vogel 2010; Acemoglu and Autor 2011). Production involves different tasks, such as managing, output, and design, and maintenance services. Exporters and nonexporters

Irene Brambilla is a professor at the Universidad Nacional de La Plata, Departamento de Economia, Calle 6 e/ 47 y 48, 1900 La Plata, Argentina; her e-mail address is irene.brambilla@econo.unlp.edu. Daniel Lederman is a deputy chief economist, LCRCE, The World Bank, 1818 H St. NW, Washington, DC 20433; his e-mail address is dlederman@worldbank.org. Guido Porto is a professor at the Universidad Nacional de La Plata, Departamento de Economia, Calle 6 e/ 47 y 48, 1900 La Plata, Argentina; his e-mail address is guido.porto@depeco.econo.unlp.edu.ar. We thank M. Busso, N. Depetris-Chauvin, and M. Olarreaga for comments and support. We also thank comments received at seminar presentations at the Universidad de La Plata, the ABCDE 2015 Conference, DEGIT XX 2015, and the Central Bank of Chile. S. Garriga provided excellent research assistance. All errors are ours. Guido Porto acknowledges support from the R4D program on Global Issues funded by Swiss National Science Foundation and the Swiss Development Cooperation.

THE WORLD BANK ECONOMIC REVIEW, VOL. 30, SUPPLEMENT pp. S126-S136 doi:10.1093/wber/lhw014 Advance Access Publication April 10, 2016

(C) The Author 2016. Published by Oxford University Press on behalf of the International Bank for Reconstruction and Development / THE WORLD BANK. All rights reserved. For permissions, please e-mail: journals.permissions@oup.com. 
fill managerial tasks with skilled workers and fill maintenance services tasks with unskilled workers. However, output and design can be performed by engineers or by blue-collar workers. Engineers can deliver higher quality goods than bluecollar workers because they are more efficient in input supervision, assembly, and general product attributes that determine quality (Bernard and Jensen 1997; Yeaple 2005; Acemoglu and Zilibotti, 2001; Verhoogen 2008; Brambilla, Lederman, and Porto 2012; Kugler and Verhoogen 2012; Bustos 2014; Bastos, Silva and Verhoogen 2014; Caron, Fally and Markusen, 2014). For given factor prices, more productive firms can afford to enter export markets, choose to produce on average higher quality products, and hire on average a higher share of engineers relative to blue-collar workers than less productive, nonexporting firms.

To test these predictions, the empirical analysis exploits detailed information of firms demand for different tasks contained in the Chilean Encuesta Nacional Industrial Anual (ENIA). The results from an instrumental variable estimator show that Chilean exporters indeed utilize a higher share of engineers over bluecollar workers than nonexporting firms. The results provide causal evidence of the skilled tasks demanded by exporters relative to nonexporters in Chile.

The rest of the article is organized as follows. Section 1 sketches a simple model of exports, quality, and the demand for engineers and blue-collar workers. Section 2 discusses the main empirical results. Section 3 concludes.

\section{A Model of Exports, Engineers, and Blue-collar Workers}

We combine elements from Verhoogen (2008) with elements from Acemoglu and Autor (2011) and Costinot and Vogel (2010) in a simple partial equilibrium model of exports and employment composition. From Verhoogen (2008), we adopt the theoretical framework underlying the idea that exporting requires quality upgrades that are inherently intensive in skilled labor. This framework can also be found in Kugler and Verhoogen (2012), Brambilla, Lederman and Porto (2012), Brambilla and Porto (2016), and Bastos, Silva and Verhoogen (2014). From Acemoglu and Autor (2011) and Costinot and Vogel (2010), we adopt an assignment model of skills to tasks. In this setting, quality for exports is produced with a collection of tasks that can be performed by workers with different skills. Exporting firms assign higher skilled workers such as engineers to fundamentally similar tasks to achieve higher quality. As a consequence, exporting firms hire a higher share of engineers over blue-collar workers than nonexporters.

We adopt a multinomial logit demand framework. The aggregate demand function of product $j$ with quality $\theta$ and price $p$ is

$$
x_{j}\left(p_{j}, \theta_{j}\right)=\exp \left(\alpha \theta_{j}-p_{j}\right),
$$

where $\alpha$ captures quality valuation which, as in Verhoogen (2008), is higher for exporting firms. 
Firms produce differentiated products in monopolistically-competitive markets. Firms can choose the level of vertical differentiation of their products $\theta$. This depends, ceteris paribus, on the quality valuation parameter $\alpha$. This gives firms the option to provide more vertical differentiation to export markets with higher $\alpha$. Exporting, in turn, incurs a fixed cost $F_{x}$.

As in Verhoogen (2008), production of output of quality $\theta$ requires activities to produce physical units and activities to produce quality itself. We assume that the production of quantity (physical units of output) is separated from the production of quality. Firms produce quantity and quality with tasks (Acemoglu and Autor 2011). To simplify the exposition, we assume that there are three different types of tasks: maintenance services (cleaning, machine and building maintenance), production and design (production activities, accounting, packaging, marketing, engineering, logistics, input control, supervision), and managerial activities (firm direction). We refer to these tasks as task 1,2 , and 3, respectively. In turn, tasks are produced by either skilled or unskilled workers which earn wages $w_{H}$ and $w_{L}$, with $w_{H}>w_{L}$.

Regarding quantity production, following Acemoglu and Autor (2011), tasks provide services that generate output. Letting $y$ be the task services, output $x$ is:

$$
x=\exp \left(\sum_{i=1}^{3} \alpha_{x}(i) \ln y_{x}(i)\right),
$$

where $y_{x}(i)$, with $i=1,2,3$, is the service of tasks $i$, and $\alpha_{x}(i)$ are the Cobb-Douglas parameters that capture the intensity of task $i$. The production function has constant return to scale, $\alpha_{x}(1)+\alpha_{x}(2)+\alpha_{x}(3)=1$. The production function of task services $y_{x}(i)$ is Ricardian. The productivity of unskilled and skilled labor in task $i$ is $a_{L x}(i)$ and $a_{H x}(i)$, respectively. We rank tasks in increasing order of skill intensity so that task 1 is the most unskilled intensive task, while task 3 is the most skilled intensive task. To determine the assignment of skills to tasks, we assume that wages are exogenous to the firm. The unit cost of using unskilled labor in task $i$ is thus $w_{L} / a_{L x}(i)$, and the unit cost of using skilled labor is $w_{H} / a_{H x}(i)$. These assumptions imply that wages of unskilled and skilled workers are the same across tasks, but the workers' productivity is not.

Without loss of generality, we consider a scenario where wages and productivity are such that

$$
\frac{a_{H x}(1)}{a_{L x}(1)}<\frac{a_{H x}(2)}{a_{L x}(2)}<\frac{w_{H}}{w_{L}}<\frac{a_{H x}(3)}{a_{L x}(3)} .
$$

This assumption implies that, in output production activities, firms allocate unskilled workers to tasks 1 and 2 and skilled workers to task 3. Given constant factor prices and labor productivity, these allocations deliver a cost function of 
output which features constant returns to scale. The marginal cost function is

$$
c=c\left(w_{L}, w_{H}\right)
$$

which depends on factor prices (and technology), but it is independent of the quantity (and quality) produced. ${ }^{1}$

Turning to the technology to produce quality, we assume that the production of quality requires the same collection of services produced by tasks 1 to 3 as in output production. The production function of quality is

$$
\theta=\lambda \exp \left(\sum_{i=1}^{3} \alpha_{\theta}(i) \ln y_{\theta}(i)\right)^{\beta}
$$

where $\lambda$ is firm productivity in quality production. Firms differ in $\lambda$ and these differences allow firms to select themselves into exporters and nonexporters and, within exporters, to define their export intensity (the share of exports in sales). To achieve an interior solution, we assume that $\beta<1$ so that the production function exhibits decreasing returns to scale and the marginal cost of quality production is increasing. ${ }^{2}$

The production function of task services $y_{\theta}$ is also Ricardian, with productivity $a_{L \theta}(i)$ and $a_{H \theta}(i),=1,2,3$. Again, without loss of generality, consider a scenario where wages and productivity are such that

$$
\frac{a_{H \theta}(1)}{a_{L \theta}(1)}<\frac{w_{H}}{w_{L}}<\frac{a_{H \theta}(2)}{a_{L \theta}(2)}<\frac{a_{H \theta}(3)}{a_{L \theta}(3)}
$$

This assumption implies that, in quality production activities, firms allocate unskilled workers to task 1 but skilled workers to tasks 2 and 3 .

Our interpretation of these assumptions is as follows. Production of output and quality require similar tasks. In basic tasks such as cleaning, janitorial services, maintenance operations and so on, firms hire similar types of unskilled workers both in output and quality production. In more sophisticated tasks such as managerial services or firm direction, firms hire similar types of skilled workers in all firm activities. The firm's sales director has similar skills as the design director. The difference is in task 2, operations and designs. In the production of

1. This result, which is a consequence of the assumption that the production of quantity and quality are independent, simplifies the solution of the model, but it is not strictly necessary for our conclusions. Extensions where the marginal cost of quantity production depends on quality can be found in Verhoogen (2008), Brambilla, Lederman, and Porto (2012), Kugler and Verhoogen (2012), and Bastos, Silva, and Verhoogen (2014). See, e.g., the review in Brambilla and Porto (2016).

2. This assumption guarantees that the choice of quality is bounded. A similar assumption is in Verhoogen (2008). 
physical output, firms hire blue-collar workers; in the production of quality, firms hire engineers.

A key difference between output and quality production is the structure of the cost function. While output production is subject to constant marginal cost $c$, quality production features increasing marginal costs. The total cost function is:

$$
F=F\left(\theta, \lambda, w_{L}, w_{H}\right)
$$

Given the production function for $\theta$, equation (6), $F_{\theta}^{\prime}>0$ and $F_{\theta}^{\prime \prime}>0$. That is, the marginal cost of producing quality is positive and increasing in the level of quality. We also know that $F_{\lambda}^{\prime}<0$ and that $\partial F_{\theta}^{\prime} / \partial \lambda<0$ (the marginal cost of producing quality decreases with productivity). Note also that, given optimal quality, the production of quality is independent of the sales of physical units of the good. In this sense, $F$ is a fixed costs (in terms of $x$ ).

Having determined the technology of producing physical units and quality, we can now study firm choices of quality and price to maximize profits (net of fixed costs), $\pi=(p-c) x(p, \theta)-F(\theta)$. The first order conditions are

$$
\begin{gathered}
p=1+c, \\
\alpha x(p, \theta)=F^{\prime}(\theta) .
\end{gathered}
$$

In this setting, firms charge the same price for goods of any quality. This price is a markup over the marginal cost $c$ (given by (4)). ${ }^{3}$ Since it is costly to produce quality, vertical differentiation occurs because firms can sell higher quantities of higher-quality products. The optimal choice of quality $\theta$ is determined by the equality of the marginal cost $\left(F^{\prime}(\theta)\right)$ and the marginal benefit (higher sales measured by $\alpha x(p, \theta))$ of quality provision. ${ }^{4}$ Since $\partial F_{\theta}^{\prime} / \partial \lambda<0$, optimal quality increases with the productivity of the firm.

To derive the demand for different types of workers, consider a firm with productivity $\lambda$ that chooses a good of quality $\theta .^{5}$ For the lowest skill tasks, task 1 , only unskilled workers are utilized, both for output production and for quality production. Total unskilled utilization is $L(1)=\alpha_{x}(1)(p-1) x / w_{L}+\alpha_{\theta}(1) F(\theta) / w_{L}$. For the highest skill tasks, task 3 , only skilled workers are utilized. Total skilled utilization is $H(3)=\alpha_{x}(3)(p-1) x / w_{H}+\alpha_{\theta}(3) F(\theta) / w_{H}$. For intermediate tasks, task 2, unskilled workers are utilized in output production and skilled workers in quality production. This can refer to an engineer, who monitors production, and a blue-collar worker, that operates machines. Unskilled utilization is

3. The result that firms charge the same price for goods of different qualities is probably unrealistic, but it is a simplification that allows us to easily illustrate the implications of productivity and of exporting on the demands of skilled tasks. See Brambilla and Porto (2016) for alternative modeling strategies.

4. For an interior solution, we assume that the marginal cost increases in $\theta$ at a sufficiently high rate (concretely, the second order condition for profit maximization is $F^{\prime \prime}(\theta)>\alpha^{2} x(p, \theta)$ ).

5. For a detailed derivation of factor demands, see Brambilla, Lederman, and Porto (2015). 
FIgURE 1. Productivity, Quality, Engineers and Blue-collar Workers

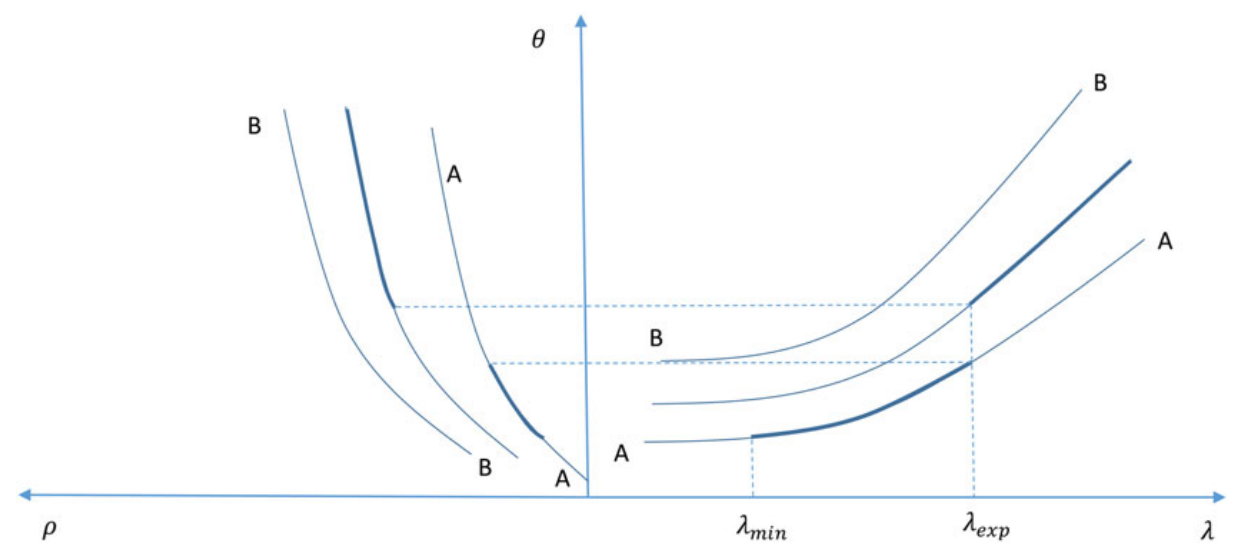

Notes: Right-Panel: firm productivity and optimal quality. The curve AA depicts the profile of domestic quality; the curve $\mathrm{BB}$ depicts the profile in foreign markets. $\lambda_{\min }$ and $\lambda_{\exp }$ are the entry cutoffs into domestic and export markets, respectively. The solid curve shows the profile of average quality.

Left-Panel: optimal quality and the ratio of engineers to blue-collar workers in employment. The curve AA corresponds to the ratio utilized in the production for the domestic market and the curve $\mathrm{BB}$, to the ratio utilized in the production for foreign markets. The solid curves depict the average ratio for different firms.

$L(2)=\alpha_{x}(2)(p-1) x / w_{L}$, while skilled utilization is $H(2)=\alpha_{\theta}(2) F(\theta) / w_{H}$. To streamline the exposition and assess the empirical implications, we focus on the ratio of engineers to blue-collar workers:

$$
\rho(\theta)=\frac{H(2)}{L(2)}=\frac{\alpha_{\theta}(2)}{\alpha_{x}(2)} \frac{F(\theta) / w_{H}}{(p-1) x / w_{L}}
$$

We want to establish whether there are differences in $\rho$ between firms, in particular between exporters and nonexporters. Firms differ in $\lambda$, quality productivity, and more productive firms choose to sell higher quality goods. A firm can separately choose a quality to sell domestically and a quality to sell abroad. As in the literature, export markets have a higher quality valuation (a higher $\alpha$ in the demand function (1) and demand higher quality. In the spirit of Verhoogen (2008), Figure 1 illustrates the model. The right panel of the figure plots the positive relationship between productivity $\lambda$ and quality $\theta$. The curve AA depicts the profile of domestic quality chosen by firms of varying $\lambda$. The curve BB, which depicts the profile in foreign markets, shifts up because of higher quality valuation abroad. There is a fixed cost of exporting and a (lower) fixed cost of entering the domestic market. This gives rise to two productivity cutoffs. Let $\lambda_{\min }$ be the cutoff productivity to enter domestic markets and $\lambda_{\text {exp }}$ be the cutoff productivity of exporters. The solid curve shows the profile of average quality as a function of 
productivity. Average quality jumps at the exporting cutoff and increases steadily with $\lambda$. On average, exporters produce higher quality products than nonexporters. In addition, within exporters, firms with higher productivity $\lambda$ will ship a larger share of their sales abroad and will produce even higher quality output.

Consider now a more productive firm (i.e., a firm with a higher $\lambda$ ) that chooses to produce a higher quality $\theta$. It is easy to show that $\rho$ is increasing in $\theta$ at a decreasing rate. ${ }^{6}$ On the left panel of figure 1 , we plot the relationship between the ratio of engineers to blue-collar workers and quality. The curve AA corresponds to the ratio utilized in the production for the domestic market. The curve $\mathrm{BB}$ is the ratio utilized in the production for foreign markets. BB lies above AA because, for a given quality, foreign markets with higher quality valuation also demand higher quantities. The solid curve depicts the average $\rho$ for different firms. As it can be seen, there is a jump in $\rho$ at the quality exporting cutoff. Exporters produce on average higher quality products and, consequently, hire on average a higher share and a higher ratio of engineers to blue-collar workers.

\section{EvIDENCE}

We use two sources of data, firm-level data, and customs records. The firm-level data come from the Encuesta Nacional Industrial Anual (ENIA), an annual industrial census run by Chile's Instituto Nacional de Estadística that interviews all manufacturing plants with 10 workers or more. It is a panel. The customs data provide administrative records on firms exports by destination. We manually matched both databases for the period 2001-2005. As a result, we built a 5-year panel database of Chilean manufacturing firms.

The data have several modules. The main module contains information on industry affiliation, ownership type, sales, exports, input use, imports of materials, workers and wages. Industry affiliation is defined at the 4-digit ISIC Revision 3 level, which totals 113 industries.

We are mostly interested in the employment information. The data on workers are presented at detailed categories, which allows us to explore the demand for different tasks. From the detailed employment records, we define the following tasks: management (directors), administrative services (accountants, lawyers), engineers (specialized skilled production workers), blue-collar activities (nonspecialized unskilled production workers), and general maintenance services (unskilled nonproduction workers).

Table 1 presents summary statistics for the key variables in our model. We present the unconditional averages as well as averages for exporting firms and nonexporting firms. In terms of employment, exporters are larger than nonexporters, as expected. On average, 39 percent of workers in Chilean firms are skilled workers and 61 percent are unskilled workers. Exporters utilize a higher

6. Note that since the production functions are Cobb-Douglas, the parameters $\alpha_{x}$ and $\alpha_{\theta}$ are fixed and, in particular, do not depend on the $x$ or $\theta$. 
Table 1. Summary Statistics National Annual Industrial Survey Chile 2001-2005

\begin{tabular}{lccc}
\hline & All firms & Exporters & Nonexporters \\
\hline A) Skilled and unskilled labor & & & \\
Log skilled employment & 2.37 & 2.47 & 2.36 \\
Log unskilled employment & 2.88 & 2.88 & 2.87 \\
Share skilled employment & 38.7 & 40.6 & 38.5 \\
Share unskilled employment & 61.3 & 59.5 & 61.5 \\
B) Tasks & & & \\
Log managerial employment & 0.60 & 0.79 & 0.58 \\
Log engineering employment & 1.22 & 1.36 & 1.21 \\
Log services employment & 1.22 & 1.34 & 1.21 \\
Log blue-collar employment & 2.71 & 2.72 & 2.71 \\
Log maintenance employment & 0.46 & 0.48 & 0.46 \\
Share managerial employment & 7.2 & 8.7 & 18.8 \\
Share engineering employment & 18.8 & 18.2 & 12.7 \\
Share services employment & 12.7 & 13.8 & 54.6 \\
Share blue-collar employment & 54.4 & 52.0 & 6.9 \\
Share maintenance employment & 6.9 & 7.3 & 2.1 \\
Ratio engineers/blue-collar & 2.5 & 4.7 & 0.00 \\
C) Exports & & & \\
Exports/sales & 0.05 & 0.32 & \\
\hline
\end{tabular}

Source: averages calculated from the Encuesta Nacional Industrial Anual (National Annual Industrial Survey), Chile 2001-2005.

share of skilled workers (41 percent) than nonexporters (39 percent). Within the skilled and unskilled categories, we are especially interested in engineering and blue-collar employment. The share of engineering employment is roughly 18.1 percent at both at exporters and nonexporters, while the share of blue-collar employment is 52.0 and 54.6 at exporters and nonexporters, respectively. The ratio of engineers to blue-collar workers is 4.7 at exporters and 2.1 at nonexporters. Finally, the average exporter ships around 32 percent of its sales abroad. Among all firms, exports accounts for only 5 percent of total firm sales.

To formally study the relationship between exporting and the composition of employment, we work with the following regression model

$$
y_{i j t}=\gamma E_{i j t}+\mathbf{x}_{i j t}^{\prime} \beta+\phi_{i}+\phi_{j t}+\varepsilon_{i j t},
$$

where $i$ is a firm, $t$ is time, and $j$ is an industry. Outcomes are denoted by $y_{i j t}$ and export intensity (the ratio of exports to total sales) is $E_{i j t}$. We add a vector $\mathbf{x}$, which includes firm level variables such as log total employment and initial conditions (sales and exporting status) interacted with year dummies to account for firm-specific trends. The regression includes firm fixed effects, $\phi_{i}$ and industry year effects, $\phi_{i t}$.

To estimate causal effects, we instrument $E_{i j t}$ following a strategy similar to Park et al. (2010), Brambilla, Lederman, and Porto (2012), Bastos, Silva, and 
Verhoogen (2014), and Brambilla and Porto (2016), among others. Intuitively, exogenous export opportunities for a firm are likely to arise when foreign demand expands and this will happen when exchange-rate variations make Chilean exports relatively cheaper. Given these exogenous changes, a firm will be more likely to take advantage of these export opportunities if it is exposed to those markets. A natural measure of destination exposure in this case is the share of a firm's exports to that destination in total firm sales. As in Brambilla, Lederman, and Porto (2012), we also interact this variable with initial firm sales (i.e., log sales in 2001) to include any firm advantages in profiting from export opportunities based on firm size. To assess the power of these instruments, we can look at the first stage results. These are reported in panel A of table 2 for four specifications. In column 1 , the specification includes only firm fixed-effects and year-effects. The instruments work well and have high explanatory power. In column 2, we add log employment to control for size. This means we compare

TAвLE 2. Exports, Engineers, and Blue-collar Workers IV Results

$\begin{array}{lll}(1) & (2) & (3)\end{array}$

\begin{tabular}{lcccc}
\hline A) First stage Results & & & & \\
Average real exchange rate & $-0.149^{* * *}$ & $-0.148^{* * *}$ & $-0.149^{* * *}$ & $-0.149^{* * *}$ \\
& $(0.023)$ & $(0.023)$ & $(0.022)$ & $(0.022)$ \\
Average real exchange rate *initial sales & $-0.0029^{*}$ & $-0.0030^{*}$ & $-0.0029^{*}$ & $-0.0029^{*}$ \\
& $(0.0017)$ & $(0.0017)$ & $(0.0016)$ & $(0.0016)$ \\
$R^{2}$ & 0.4129 & 0.4147 & 0.4144 & 0.4146 \\
$F$-statistic & 888.09 & 882.96 & 888.42 & 884.31 \\
Prob $>F$ & 0.0000 & 0.0000 & 0.0000 & 0.0000 \\
B) Tasks & & & & \\
Share managers & $-0.01^{* *}$ & -0.01 & -0.01 & -0.009 \\
& $(0.006)$ & $(0.005)$ & $(0.005)$ & $(0.005)$ \\
Share engineers & $0.09^{* * *}$ & $0.10^{* * *}$ & $0.10^{* * *}$ & $0.10^{* * *}$ \\
& $(0.031)$ & $(0.031)$ & $(0.032)$ & $(0.032)$ \\
Share services & -0.009 & 0.009 & 0.009 & -0.009 \\
& $(0.008)$ & $(0.007)$ & $(0.007)$ & $(0.007)$ \\
Share blue-collar & $-0.07^{* *}$ & $-0.08^{* *}$ & $-0.08^{* * *}$ & $-0.08^{* *}$ \\
& $(0.031)$ & $(0.033)$ & $(0.034)$ & $(0.034)$ \\
Share maintenance & $-0.01^{* *}$ & $-0.01^{*}$ & $-0.01^{*}$ & $-0.01^{*}$ \\
& $(0.005)$ & $(0.004)$ & $(0.004)$ & $(0.004)$ \\
Ratio engineers to blue-collar & $14.42^{* *}$ & $13.54^{* *}$ & $13.67^{* *}$ & $13.58^{* *}$ \\
& $(6.34)$ & $(6.13)$ & $(6.37)$ & $(6.33)$ \\
Firm and year FE & Yes & Yes & Yes & yes \\
Log employment & No & Yes & Yes & Yes \\
Industry-specific trends & No & No & Yes & Yes \\
Firm-specific trends & No & No & No & Yes \\
\hline
\end{tabular}

Notes: IV-FE regressions of employment shares on export intensity (exports/sales). The instruments are the weighted average the real exchange rate of a firm export partners and the weighted average of the real gdp of a firm export destinations. Column (1): firm fixed-effects and year fixed-effects; column (2): adds log total employment (firm size); column (3): adds controls for industry-specific trends (i.e., interactions between year dummies and industry dummies); column (4): adds initial conditions to control for firm-specific trends. Data are from the Encuesta Nacional Industrial Anual (National Annual Industrial Survey), Chile 2001-2005. 
firms of equal size, with different export intensity. To account for industry trends, such as industry-specific growth processes, we add in column 3 interactions between year dummies and industry dummies. In column 4 , we also add initial conditions to account for firm-specific trends (Brambilla, Lederman, and Porto 2012). The results are very robust and the magnitudes of the coefficients are also stable across specifications.

The causal impacts of export intensity on employment are reported in panel B of table 2. We find that the share of engineering employment is higher among exporters. This holds for all our specifications, that is, conditional on firm- and year-fixed effects only (column 1), conditional on size and fixed effects (column 2 ), and also conditional on industry- and firm-specific trends (columns 3 and 4). Evaluated at the average share of export sales, conditional on exporting (32 percent in our data), an exporter hires 3.2 percentage points more engineers than a nonexporter. This is compensated with lower shares of blue-collar employment. The shares of all other types of employment are not statistically different, except for the share of maintenance workers, which is only marginally smaller among exporting firms. These results can also be seen in terms of the ratio of engineers to blue-collar works. In all four specifications, the ratio increases with exports. These findings are consistent with our theory.

\section{Conclusions}

Chilean exporters demand more engineers relative to blue-collar workers. Foreign consumers value product quality and quality is intensive in engineering tasks. A simple partial equilibrium model formalized these mechanisms and the evidence from a panel of Chilean firms supports the model predictions. The findings have implications for empirical research and policy design. The notion that trade, and exports in particular, affects the wage premium and thus wage-inequality needs to be carefully assessed. Exporting from developing countries may raise the demand for specific sets of skills, thus creating potential inequality even within skilled labor categories. In Chile, our results show that export opportunities boost the demand for technical skills such as engineering skills. These conclusions should contribute to our understanding of the skilled tasks needed for exports, the role of potential education policies consistent with a successful long-run export performance, and the design of social policies to reduce wage inequality and help the losers from trade.

\section{REFERENCES}

Acemoglu, D., and D. Autor. 2011. "Skills, Tasks, and Technologies: Implications for Employment Earnings," in The Handbook of Labor Economics, vol. 4b., ed. O. Ashenfelter, and D. Card, Amsterdam: Elsevier, 1043-171.

Acemoglu, D., and F. Zilibotti. 2001. "Productivity Differences.” Quarterly Journal of Economics 116 (2): 563-606. 
Bastos, P., J. Silva, and E. Verhoogen. 2014. "Export Destinations and Input Prices: Evidence from Portugal," mimeo.

Bernard, A. B., and J.B. Jensen. 1997. "Exporters, Skill Upgrading, and the Wage Gap.” Journal of International Economics 42: 3-31.

. 1999. "Exceptional Exporter Performance: Cause, Effect, or Both?” Journal of International Economics 47 (1): 1-25.

Bernard, A., B. Jensen, S. Redding, and P. Schott. 2007. "Firms in International Trade." Journal of Economic Perspectives 21 (3): 105-30.

Brambilla, I., D. Lederman, and G. Porto. 2012. "Exports, Export Destinations and Skills.” American Economic Review 102 (7): 3406-38.

- 2015. "Exporting and the Demand for Skilled Tasks." mimeo Universidad Nacional de La Plata.

Brambilla, I., and G. Porto. 2016. "High-Income Export Destinations, Quality and Wages.” Journal of International Economics 98: 21-35.

Bustos, P. 2014. "The Impact of Trade Liberalization on Skill Upgrading. Evidence from Argentina," mimeo CREI.

Caron, J., T. Fally, and J. Markusen. 2014. "International Trade Puzzles: A Solution Linking Production and Preferences," forthcoming in the Quarterly Journal of Economics.

Costinot, A., and J. Vogel. 2010. "Matching and Inequality in the World Economy," Journal of Political Economy 118 (4): 747-86.

Kugler, M., and E. Verhoogen. 2012. "Prices, Plant Size, and Product Quality," Review of Economic Studies 79 (1): 307-39.

Melitz, M. 2003. “The Impact of Trade on Intra-Industry Reallocations and Aggregate Industry Productivity," Econometrica 71 (6): 1695-1725.

Park, A., D. Yang, X. Shi, and Y. Jiang. 2010. "Exporting and Firm Performance: Chinese Exporters and the Asian Financial Crisis," The Review of Economics and Statistics 92 (4): 822-842.

Verhoogen, E. 2008. "Trade, Quality Upgrading, and Wage Inequality in the Mexican Manufacturing Sector," Quarterly Journal of Economics 123 (2): 489-530.

Yeaple, S. 2005. “A Simple Model of Firm Heterogeneity, International Trade and Wages," Journal of International Economics 65: 1-20. 